\title{
Short-term Exposure of PM2.5 and PM10 Increases the Number of Outpatients with Eczema in Guangzhou: A Time-Series Study
}

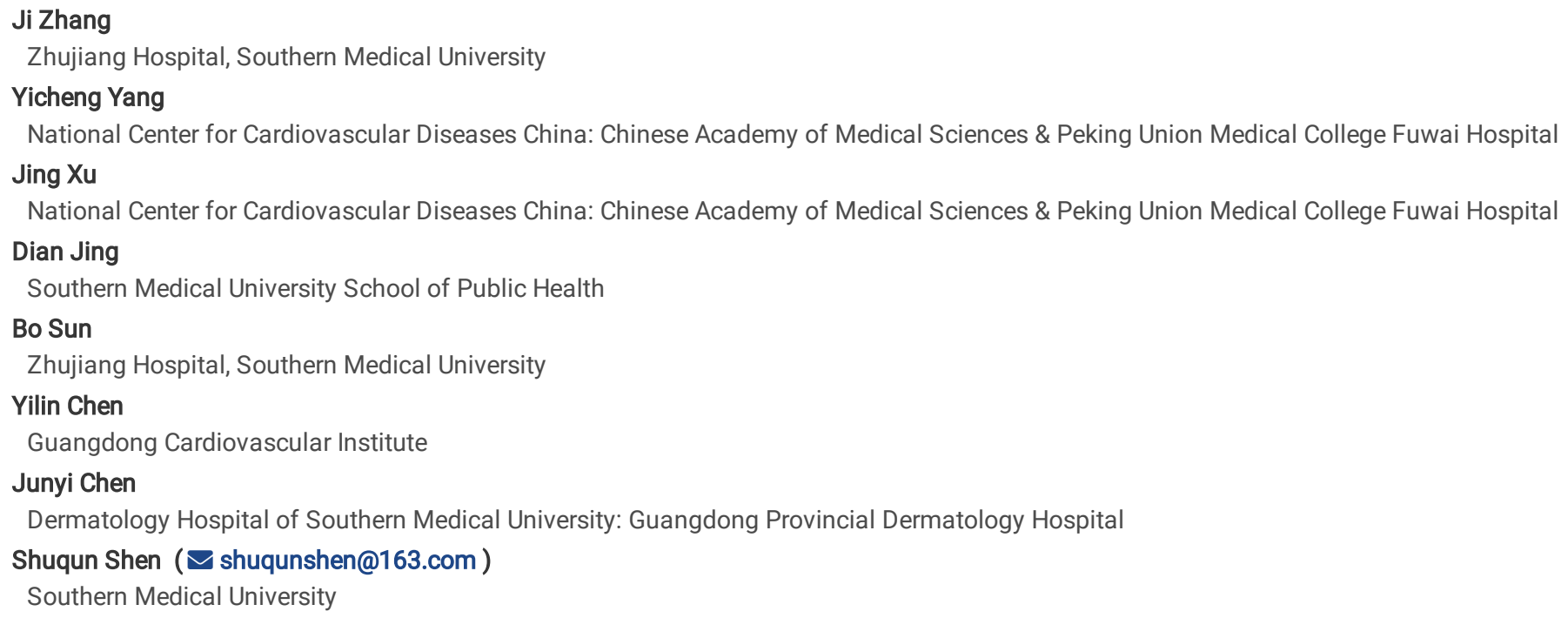

Research article

Keywords: Short-term Exposure, Particulate matter, PM2.5, PM10, Air pollution, Eczema, Outpatients

Posted Date: November 18th, 2020

DOI: https://doi.org/10.21203/rs.3.rs-108684/v1

License: (c) (i) This work is licensed under a Creative Commons Attribution 4.0 International License. Read Full License 


\section{Abstract}

Background: The worldwide prevalence of eczema has continued to rise over the past decades. This has led to emphasis on the association between air pollution and eczema. This study investigated the relationship between daily exposure to air pollution and the number of eczema outpatient visits in Guangzhou with the overarching goal of providing novel insights on the interventions for eczema aggravation and prevention.

Methods: Daily air pollution data, meteorological data, and number of eczema outpatients were obtained from $18^{\text {th }}$ January 2013 to $31^{\text {st }}$ December 2018 in Guangzhou. A generalized additive model with Poisson distribution was used to assess the association between the number of eczema outpatient visits and short-term exposure of $\mathrm{PM}_{2.5}$ and $\mathrm{PM}_{10}$. In addition, the effect of $\mathrm{PM}_{2.5}$ and $\mathrm{PM}_{10}$ by age ( $<65$ years, $\geq 65$ years) and gender was evaluated.

Results: A total of 293,343 eczema outpatient visits were recorded. The obtained results indicated that a $10 \mu \mathrm{g} / \mathrm{m}^{3}$ increase of the same day/ lag 1 day/ lag 2 days $\mathrm{PM}_{2.5}$ was associated with increments of $2.33 \%(\mathrm{RR}=1.0233,95 \% \mathrm{Cl}: 1.0206-1.0260, P<0.001), 1.81 \%(\mathrm{RR}=1.0181,95 \% \mathrm{Cl}: 1.0153-1.0209$, $P<0.001)$, and $0.95 \%(\mathrm{RR}=1.0095,95 \% \mathrm{Cl}: 1.0068-1.0123, P<0.001)$ in eczema outpatients risk, respectively. On the other hand, a $10 \mu \mathrm{g} / \mathrm{m}^{3}$ increase of $\mathrm{PM}_{10}$ was associated with eczema outpatients risk increments of $1.97 \%(\mathrm{RR}=1.0197,95 \% \mathrm{Cl}: 1.0177-1.0217, P<0.001), 1.65 \%(\mathrm{RR}=1.0165,95 \% \mathrm{Cl}: 1.0145$ $1.0186, P<0.001)$, and $0.98 \%(\mathrm{RR}=1.0098,95 \% \mathrm{Cl}: 1.0078-1.0118, P<0.001)$, respectively. Furthermore, the effects of PM on the increment of eczema were similar in the male and female groups. Results obtained after age stratification analyses indicated that the strongest positive association between $\mathrm{PM}_{2.5}$ exposure and eczema were observed at lag 0 day with the percent changes being $4.72 \%(95 \% \mathrm{Cl}, 4.18-5.28 \%, P<0.001), 1.92 \%(95 \% \mathrm{Cl}: 1.65-2.19 \%$, $P<0.001)$ and $3.34 \%(95 \% \mathrm{Cl}, 2.9-3.78 \%, P<0.001)$ in $<12$ years old, $\geq 12$ and $<65 y$ ears old, and $\geq 65$ years old groups, respectively.

Conclusion: Short-term exposure of $\mathrm{PM}_{2.5}$ and $\mathrm{PM}_{10}$ increases the number of eczema outpatients especially among children and the elderly. This study has provided a further understanding of the relationship between air pollutants and eczema, which will benefit disease prevention and lower the health burden.

\section{Background}

Eczema is a group of common inflammatory skin diseases. Patients may develop different skin lesions and relapsing pruritus in the different stages, thereby causing considerable physical and psychological burden on the patients ${ }^{1-3}$. The worldwide prevalence of eczema has been rising continuously over the past decades ${ }^{4}, 5$. The available clinical treatments only improve the symptoms as opposed to curing the disease. Therefore, the lack of a cure for eczema highlights the importance of prevention. A previous study has reported that identification of the underlying modifiable risk factors for eczema including environmental stimuli plays a decisive role in the prophylactic management of the disease ${ }^{6}$.

The rapid development in China has resulted in air pollution becoming worse ${ }^{7,8}$. Among the many air pollutants, particulate matter (PM) is derived from anthropogenic activities of fossil fuel combustion, mostly contributed by the consumption of fuel by vehicles ${ }^{9}$. PM is a complicated mixture with alternative concentration, particle diameter, and chemical properties in various spaces and time ${ }^{10}$. According to the particles' aerodynamic diameter, PM can be categorized into $\mathrm{PM}_{0.1}$ (particle diameter $\leq 0.1 \mu \mathrm{m}$ ), $\mathrm{PM}_{2.5}$ (particle diameter $\leq 2.5 \mu \mathrm{m}$ ), and $\mathrm{PM}_{10}$ (particle diameter $\leq 10 \mu \mathrm{m}{ }^{11}$. In addition to the genetic background, dietary habits, lifestyle, and societal status have also been associated with the pathogenic condition of skin diseases ${ }^{12,13}$ Accumulating scientific evidence has reported the effects of PM on the development of eczema and dermatitis ${ }^{14,15}$. A meta-analysis study reported that an estimated increase of $10 \mu \mathrm{g} / \mathrm{m}^{3}$ in $\mathrm{PM}_{2.5}$ and $\mathrm{PM}_{10}$ can lead to a $1.60 \%(0.45-2.82)$ and $1.01 \%(0.08-2.05)$ increase of skin diseases risk, respectively ${ }^{16}$. However, the study had limited epidemiologic findings, and the existing evidence was inconsistent ${ }^{17}$.

Guangzhou is one of the most densely populated cities in China. A previous study reported that PM has become one of the main sources of air pollution in Guangzhou due to the rapid industrial development and advanced transportation ${ }^{18}$. Therefore, this study investigated the association between daily air pollution exposure and the number of outpatients with eczema in Guangzhou. Additionally, the above associations were also evaluated in different ages, and gender subgroups. The main aim of the study was to identify the potential environmental risk factors and to provide novel insights on the interventions for eczema aggravation and prevention.

\section{Materials And Methods Study setting}

Guangzhou, the capital city of Guangdong province, is one of the developed cities in China with an approximate population of 14.9 million in 2018 . The city, located at $23^{\square} 10^{\prime} \mathrm{N}, 113^{\square} 18^{\prime} \mathrm{E}$, has a typical subtropical humid-monsoon climate with an average annual temperature and rainfall of $22^{\circ} \mathrm{C}$ and $1500-$ $2000 \mathrm{~mm}$, respectively. In addition, Guangzhou is the top-ranking commercial and manufacturing city in China. Therefore, the problem of air pollution in the city as a result of economic advancement should not be underestimated. In 2019 , the average concentrations of $\mathrm{PM}_{2.5}, \mathrm{PM}_{10}, \mathrm{NO}_{2}, \mathrm{SO}_{2}$, and $\mathrm{O}_{3}$ in Guangzhou were $30 \mathrm{~g} / \mathrm{m}^{3}, 53 \mathrm{~g} / \mathrm{m}^{3}, 45 \mathrm{~g} / \mathrm{m}^{3}, 7 \mathrm{~g} / \mathrm{m}^{3}$, and $178 \mathrm{~g} / \mathrm{m}^{3}$, respectively ${ }^{19}$

\section{Data sources}




\section{Patient Data}

The Dermatology Hospital of Southern Medical University, located in Tianhe district, Guangzhou, is a large-scale dermatology specialty and brand influence hospital in South China. The hospital has the largest number of eczema outpatient visits in Guangzhou. This study enrolled outpatients who were diagnosed with eczema coded as L30.902 according to the World Health Organization's International Classification of Diseases (the 10th version (ICD-10)) in the hospital from 18th January 2013 to 31st December 2018. If recurrent eczema occurred within 21 days of a previous outpatient visit, it was regarded as a single eczema event.

\section{Air Pollution and Meteorological Data}

Air quality monitoring data was obtained from the public sharing system of Guangzhou Environmental Monitoring Center

(http://210.72.1.33:8023/gzaqi_new/

RealTimeDate.html). Data recorded in the system was obtained from 11 national air quality monitor stations in Guangzhou and the daily average air quality data was used for our analyses. Daily average concentrations of $\mathrm{PM}_{2.5}, \mathrm{PM}_{10}, \mathrm{NO}_{2}, \mathrm{SO}_{2}$, and $\mathrm{O}_{3}$ during the period ranging from 18 th January 2013 to 31 st December 2018 were also collected. Daily meteorological data, including mean humidity and temperature, were obtained from the China Meteorological Data Sharing Service System based on data from different meteorological stations in Guangzhou, and used for analyses. Both air pollution and meteorology data followed the quality control programs which are mandated by the Chinese government.

\section{Statistical Analyses}

A generalized additive model (GAM) with Poisson distribution was used to assess the association between eczema outpatient visits and short-term exposure of $\mathrm{PM}_{2.5}$ and $\mathrm{PM}_{10}{ }^{20}$. Lag 0-3 days were used to explore the cumulative exposure and displacement effects of PM and other pollutants ${ }^{21}$. This study used a single pollutant model to examine the independent association between PM and eczema admission. In addition, we built a twopollutant model to control the potential confounding effects of other pollutants ${ }^{22}$. These models can be represented as follows:

$$
\begin{aligned}
& \log \left(\mu_{t}\right)=\alpha+\sum \beta_{i} X_{t i}+N S(\text { temperature }, d f=3)+N S\left(\text { humidity }_{t}, d f=3\right) \\
& +N S\left(\text { time }_{t}, d f=10 / \text { year }\right)+\gamma D O W_{t}
\end{aligned}
$$

where $\mu_{t}$ represents the expected number of eczema outpatients on day $t$, $\mathrm{a}$ is the intercept; $X_{i t}$ represents the concentrations of pollutants (PM ${ }_{2.5}$, PM ${ }_{10}$, $\mathrm{NO}_{2}, \mathrm{SO}_{2}$, and $\mathrm{O}_{3}$ ) on day $t, i=1$ or $i=2$ represents single pollutant model or two-pollutant model respectively; and $\beta_{i}$ stands for the coefficient of $X_{i}$. A natural cubic spline function (NS) with 10,3, and 3 degrees of freedom (df) was used to capture the nonlinear relationships of time trend, temperature, and humidity ${ }^{23}$. In our model, day of week $\left(D O W_{t}\right)$ was set in the form of categorical variables, while $y$ represents the effect of $D O W_{t}$ on eczema outpatients.

Age and gender stratification analyses using potential individual-level effect modifiers were also conducted. This study used the above basic models to examine outcomes by stratification of age (<65 years, $\geq 65$ years) and gender for the purpose of exploring the potential modification.

In addition, the dfs for temperature, humidity, and time used in the above models were assessed using Akaike information criterion for quasi-Poisson (QAIC). The minimum value of Q-AIC represented the best goodness and the optimum of dfs. In order to check the robustness of our modeling strategies, sensitivity analyses were done by changing the $\mathrm{df}$ for temperature (2-4), humidity (2-4), and calendar time (9-11 per year) to control time trend ${ }^{24}$. $\mathrm{R}$ software version 4.0 .2 was used to conduct all the analyses and a $P$ value $<0.05$ was considered to be statistically significant in all statistical analyses.

\section{Results}

\section{Data description}

In this study, a total of 293,343 eczema outpatients were recorded in the Dermatology Hospital of Southern Medical University from 18 th January 2013 to 31 st December 2018. Table 1 shows the descriptive statistics of daily eczema outpatients, air pollutants, and meteorological variables. The average number of daily eczema outpatients in the hospital was190 in 2018, while the average concentrations of air pollutants including $\mathrm{PM}_{2.5}, \mathrm{PM}_{10}, \mathrm{NO}_{2}, \mathrm{SO}_{2}$, and $\mathrm{O}_{3}$ were $34.7 \mu \mathrm{g} / \mathrm{m}^{3}, 55.7 \mu \mathrm{g} / \mathrm{m}^{3}, 48.1 \mu \mathrm{g} / \mathrm{m}^{3}, 9.6 \mu \mathrm{g} / \mathrm{m}^{3}$, and $50.7 \mu \mathrm{g} / \mathrm{m}^{3}$, respectively. In addition, the annual mean temperature and humidity were $22.3^{\circ} \mathrm{C}$ and $81.7 \%$, respectively. With the exception of temperature $(F$ value $=0.313, p$ value $=0.905)$, the annual average values of all other variables were significantly different from 2013 to 2018. Furthermore, there was an increased trend of eczema outpatient visits. 
Table 1

Daily number of eczema outpatients, meteorological factors, and air pollutants in Guangzhou (2013/1/18-2018/12/31)

\begin{tabular}{|c|c|c|c|c|c|c|c|c|}
\hline & 2013 & 2014 & 2015 & 2016 & 2017 & 2018 & $F$ & $P$ \\
\hline $\begin{array}{l}\text { Eczema } \\
\text { outpatients }\end{array}$ & $\begin{array}{l}75.261 \pm \\
23.840\end{array}$ & $\begin{array}{l}93.688 \pm \\
31.839\end{array}$ & $\begin{array}{l}131.406 \pm \\
37.233\end{array}$ & $\begin{array}{l}155.644 \pm \\
43.374\end{array}$ & $\begin{array}{l}180.638 \pm \\
48.581\end{array}$ & $\begin{array}{l}190.845 \pm \\
48.430\end{array}$ & 478.389 & $<.001$ \\
\hline $\begin{array}{l}\text { Temperature } \\
{ }^{\mathrm{a}}\left({ }^{\circ} \mathrm{C}\right)\end{array}$ & $\begin{array}{l}22.160 \pm \\
5.585\end{array}$ & $\begin{array}{l}21.768 \pm \\
6.580\end{array}$ & $\begin{array}{l}22.229 \pm \\
5.927\end{array}$ & $\begin{array}{l}22.019 \pm \\
6.395\end{array}$ & $\begin{array}{l}22.136 \pm \\
5.837\end{array}$ & $\begin{array}{l}22.255 \pm \\
6.177\end{array}$ & 0.313 & 0.905 \\
\hline Humidity *(\%) & $\begin{array}{l}81.296 \pm \\
11.546\end{array}$ & $\begin{array}{l}78.448 \pm \\
10.628\end{array}$ & $\begin{array}{l}78.057 \pm \\
8.907\end{array}$ & $\begin{array}{l}81.991 \pm \\
9.698\end{array}$ & $\begin{array}{l}80.942 \pm \\
11.373\end{array}$ & $\begin{array}{l}81.685 \pm \\
10.203\end{array}$ & 9.472 & $<.001$ \\
\hline $\mathrm{PM}_{2.5}{ }^{*}\left(\mathrm{mg} / \mathrm{m}^{3}\right)$ & $\begin{array}{l}50.165 \pm \\
27.241\end{array}$ & $\begin{array}{l}49.350 \pm \\
24.731\end{array}$ & $\begin{array}{l}38.958 \pm \\
21.112\end{array}$ & $\begin{array}{l}34.163 \pm \\
17.220\end{array}$ & $\begin{array}{l}35.033 \pm \\
19.055\end{array}$ & $\begin{array}{l}34.663 \pm \\
21.135\end{array}$ & 40.575 & $<.001$ \\
\hline $\mathrm{PM}_{10}{ }^{*}\left(\mathrm{mg} / \mathrm{m}^{3}\right)$ & $\begin{array}{l}72.139 \pm \\
34.403\end{array}$ & $\begin{array}{l}67.476 \pm \\
30.655\end{array}$ & $\begin{array}{l}60.636 \pm \\
28.122\end{array}$ & $\begin{array}{l}54.739 \pm \\
25.081\end{array}$ & $\begin{array}{l}56.388 \pm \\
27.007\end{array}$ & $\begin{array}{l}55.658 \pm \\
27.538\end{array}$ & 21.298 & $<.001$ \\
\hline $\mathrm{NO}_{2}{ }^{*}\left(\mathrm{mg} / \mathrm{m}^{3}\right)$ & $\begin{array}{l}51.237 \pm \\
21.476\end{array}$ & $\begin{array}{l}44.093 \pm \\
18.826\end{array}$ & $\begin{array}{l}45.188 \pm \\
17.063\end{array}$ & $\begin{array}{l}43.716 \pm \\
18.109\end{array}$ & $\begin{array}{l}49.664 \pm \\
19.595\end{array}$ & $\begin{array}{l}48.064 \pm \\
19.605\end{array}$ & 9.315 & $<.001$ \\
\hline $\mathrm{SO}_{2}{ }^{*}\left(\mathrm{mg} / \mathrm{m}^{3}\right)$ & $\begin{array}{l}20.798 \pm \\
8.447\end{array}$ & $\begin{array}{l}20.953 \pm \\
15.474\end{array}$ & $\begin{array}{l}12.998 \pm \\
5.216\end{array}$ & $\begin{array}{l}11.954 \pm \\
3.783\end{array}$ & $\begin{array}{l}11.739 \pm \\
3.645\end{array}$ & $9.603 \pm 3.262$ & 135.621 & $<.001$ \\
\hline $\mathrm{O}_{3}{ }^{*}\left(\mathrm{mg} / \mathrm{m}^{3}\right)$ & $\begin{array}{l}61.797 \pm \\
36.736\end{array}$ & $\begin{array}{l}57.796 \pm \\
33.119\end{array}$ & $\begin{array}{l}47.715 \pm \\
24.465\end{array}$ & $\begin{array}{l}47.175 \pm \\
24.994\end{array}$ & $\begin{array}{l}50.253 \pm \\
27.124\end{array}$ & $\begin{array}{l}50.678 \pm \\
25.623\end{array}$ & 14.398 & $<.001$ \\
\hline \multicolumn{9}{|c|}{ a $F=0.313, p$ value $=0.905$} \\
\hline${ }^{\star} p$ value $<0.001$ & & & & & & & & \\
\hline
\end{tabular}

Obtained results indicated that the correlation coefficients between $\mathrm{PM}_{2.5}$ and temperature, humidity, $\mathrm{PM}_{10}, \mathrm{NO}_{2}, \mathrm{SO}_{2}$, and $\mathrm{O}_{3}$ were $0.32,0.22,0.94,0.73$, 0.60 , and 0.31 , respectively. $\mathrm{PM}_{2.5}$ was negatively correlated with temperature and humidity, and positively correlated with $\mathrm{PM}_{10}, \mathrm{NO}_{2}$, $\mathrm{SO}_{2}$, and $\mathrm{O}_{3}$. On the other hand, the correlation coefficients between $\mathrm{PM}_{10}$ and temperature, humidity, $\mathrm{PM}_{2.5}, \mathrm{NO}_{2}, \mathrm{SO}_{2}$, and $\mathrm{O}_{3}$ were $0.24,0.26,0.94,0.80,0.44$, and 0.35 , respectively. Similarly, $\mathrm{PM}_{10}$ was negatively correlated with temperature and humidity, and positively correlated with $\mathrm{PM}_{2.5}, \mathrm{NO}_{2}, \mathrm{SO}_{2}$, and $\mathrm{O}_{3}$. The highest Pearson correlations were observed between $\mathrm{PM}_{2.5}$ and $\mathrm{PM}_{10}$ (Supplementary Table 1).

\section{Distributed lag nonlinear model analyses}

The smallest Q-AIC of 27558.6 was obtained with per year df of 3, 3, 10 for temperature, humidity, and time, respectively (Supplementary Table 2). This result formed the basis for the distributing lag nonlinear model analyses which followed.

Results obtained from the single pollutant model indicated that a per $10 \mathrm{~g} / \mathrm{m}^{3}$ increase of $\mathrm{PM}_{2.5}$ led to a $2.33 \%(\mathrm{RR}=1.0233,95 \% \mathrm{Cl}: 1.0206-1.0260, P<$ 0.001), 1.81\% (RR = 1.0181, 95\% Cl: 1.0153-1.0209, $P<0.001), 0.95 \%(\mathrm{RR}=1.0095,95 \% \mathrm{Cl}: 1.0068-1.0123, P<0.001)$, and 0.29\% (RR $=1.0095,95 \% \mathrm{Cl}$ : 1.0029-1.0056, $P=0.274$ ) increase in the number of daily eczema outpatients at lag $0-3$ days, respectively. In addition, a per $10 \mathrm{~g} / \mathrm{m}^{3}$ increase of $\mathrm{PM} / 0$ caused 1.97\% (RR = 1.0197, 95\%Cl: 1.0177-1.0217, $P<0.001), 1.65 \%(\mathrm{RR}=1.0165,95 \% \mathrm{Cl}: 1.0145-1.0186, P<0.001), 0.98 \%(\mathrm{RR}=1.0098,95 \% \mathrm{Cl}$ : $1.0078-1.0118, P<0.001)$, and $0.52 \%(R R=1.0052,95 \% \mathrm{Cl}: 1.0032-1.0071, P=0.008))$ increase in the number of daily eczema outpatients at lag $0-3$ days, respectively (Table 2 ).

Table 2

The RR and percent change of eczema risk associated with a $10 \mathrm{mg} / \mathrm{m}^{3}$ increase of $\mathrm{PM}_{2.5}$ and $\mathrm{PM}_{10}$

\begin{tabular}{|c|c|c|c|c|}
\hline Pollutant(per $10 \mathrm{mg} / \mathrm{m}^{3}$ ) & Lag Day & RR & PC (\%) & p_value \\
\hline \multirow[t]{4}{*}{$\mathrm{PM}_{2.5}$} & Lag 0 & $1.0233(1.0206-1.0260)$ & $2.33(2.06-2.6)$ & $<.001$ \\
\hline & Lag 1 & $1.0181(1.0153-1.0209)$ & $1.81(1.53-2.09)$ & $<.001$ \\
\hline & Lag 2 & $1.0095(1.0068-1.0123)$ & $0.95(0.68-1.23)$ & $<.001$ \\
\hline & $\operatorname{Lag} 3$ & $1.0029(1.0003-1.0056)$ & $0.29(0.03-0.56)$ & 0.274 \\
\hline \multirow[t]{4}{*}{$\mathrm{PM}_{10}$} & Lag 0 & $1.0197(1.0177-1.0217)$ & $1.97(1.77-2.17)$ & $<.001$ \\
\hline & Lag 1 & $1.0165(1.0145-1.0186)$ & $1.65(1.45-1.86)$ & $<.001$ \\
\hline & Lag 2 & $1.0098(1.0078-1.0118)$ & $0.98(0.78-1.18)$ & $<.001$ \\
\hline & Lag 3 & $1.0052(1.0032-1.0071)$ & $0.52(0.32-0.71)$ & 0.008 \\
\hline
\end{tabular}


On the other hand, results obtained from the two-pollutant model analyses indicated that a per $10 \mathrm{~g} / \mathrm{m}^{3}$ increase of $\mathrm{PM}_{2.5}$ adjusting for $\mathrm{PM}_{10}, \mathrm{NO}_{2}, \mathrm{SO}_{2}$, and $\mathrm{O}_{3}$ led to a $1.29 \%(\mathrm{RR}=1.0129,95 \% \mathrm{Cl}: 1.0113-1.0145), 2.01 \%(\mathrm{RR}=1.0201,95 \% \mathrm{Cl}: 1.018-1.0223), 2.54 \%(\mathrm{RR}=1.0254,95 \% \mathrm{Cl}: 1.0223-1.0285)$, and $1.46 \%(R R=1.0146,95 \% \mathrm{Cl}: 1.0129-1.016)$ increase of eczema outpatient visits at lag $0-3$ days, respectively. Besides, per $10 \mathrm{~g} / \mathrm{m}^{3}$ increase of $\mathrm{PM}_{10}$ increased eczema outpatient visits by $1.75 \%(\mathrm{RR}=1.0175,95 \% \mathrm{Cl}: 1.0158-1.0192), 2.34 \%(\mathrm{RR}=1.0234,95 \% \mathrm{Cl}: 1.021-1.0258)$, and $1.4 \%(\mathrm{RR}=$ $1.014,95 \% \mathrm{Cl}: 1.0125-1.0154)$ at lag $0-3$ days, respectively, after adjusting for $\mathrm{NO}_{2}, \mathrm{SO}_{2}$, and $\mathrm{O}_{3}(\mathrm{Table} 3)$.

Table 3

The RR and percent change of eczema risk associated with a $10 \mathrm{mg} / \mathrm{m}^{3}$ increase of $\mathrm{PM}_{2.5}$ and $\mathrm{PM}_{10}$ under the two-pollutant model

\begin{tabular}{|llll|}
\hline Pollutant(per $\left.10 \mathrm{mg} / \mathrm{m}^{3}\right)$ & Model type & $\mathrm{R}$ & $\mathrm{PC}(\%)$ \\
\hline $\mathrm{PM}_{2.5}{ }^{*}$ & $\mathrm{PM}_{2.5}+\mathrm{PM}_{10}$ & $1.0129(1.0113-1.0145)$ & $1.29(1.13-1.45)$ \\
& $\mathrm{PM}_{2.5}+\mathrm{NO}_{2}$ & $1.0201(1.018-1.0223)$ & $2.01(1.8-2.23)$ \\
& $\mathrm{PM}_{2.5}+\mathrm{SO}_{2}$ & $1.0254(1.0223-1.0285)$ & $2.54(2.23-2.85)$ \\
\hline $\mathrm{PM}_{2.5}+\mathrm{O}_{3}$ & $1.0146(1.0129-1.0163)$ & $1.46(1.29-1.63)$ \\
\hline $\mathrm{PM}_{10}{ }^{*}$ & $\mathrm{PM}_{10}+\mathrm{NO}_{2}$ & $1.0175(1.0158-1.0192)$ & $1.75(1.58-1.92)$ \\
\hline $\mathrm{PM}_{10}+\mathrm{SO}_{2}$ & $1.0234(1.021-1.0258)$ & $2.34(2.1-2.58)$ \\
\hline${ }^{*} p$ value < 0.001 & $\mathrm{PM}_{10}+\mathrm{O}_{3}$ & $1.014(1.0125-1.0154)$ & $1.4(1.25-1.54)$ \\
\hline RR: risk ratio; $\mathrm{PC}$ : percentage change & & \\
\hline
\end{tabular}

\section{Stratification analyses}

Results obtained after gender stratification analyses indicated that a $10 \mu \mathrm{g} / \mathrm{m}^{3}$ increase of $\mathrm{PM}_{2.5}$ concentrations caused a $2.32 \%$ (95\%Cl: $2.03-2.61 \%$, $P<0.001), 1.77 \%$ (95\%Cl: $1.47-2.07 \%, P<0.001), 0.9 \%$ (95\% Cl: $0.61-1.19 \%, P=0.002)$, and $0.16 \%(95 \% \mathrm{Cl}:-0.13-0.44 \%, P=0.579)$ increase in the risk of eczema outpatient visits at lag 0-3 days, respectively, in the male group. On the other hand, the percentage change of eczema outpatients in the female group were $2.31 \%(95 \% \mathrm{Cl}$ : $2.01-2.61 \%, P<0.001), 1.82 \%(95 \% \mathrm{Cl}: 1.51-2.13 \%, P<0.001), 0.99 \%(95 \% \mathrm{Cl}: 0.68-1.29 \%, P=0.001)$, and $0.41 \%(95 \% \mathrm{Cl}$ : $0.12-0.71 \%, P=0.160)$ at lag $0-3$ days, respectively. In addition, age stratification analyses results indicated that the strongest positive association between $\mathrm{PM}_{2.5}$ exposure and eczema were observed at lag 0 day with the percent changes being $4.72 \%(95 \% \mathrm{Cl}, 4.18-5.28 \%, P<0.001), 1.92 \%(95 \% \mathrm{Cl}$ : $1.65-2.19 \%, P<0.001)$ and $3.34 \%(95 \% \mathrm{Cl}, 2.9-3.78 \%, P<0.001)$ in the $<12$ years old, $\geq 12$ and $<65$ years old, and $\geq 65$ years old groups, respectively. Gradual weakening trends could be observed at lag 1-3 days.

Furthermore, a $10 \mu \mathrm{g} / \mathrm{m}^{3}$ increase of $\mathrm{PM}_{10}$ concentrations caused a $1.97 \%(95 \% \mathrm{Cl}: 1.76-2.18 \%, P<0.001), 1.6 \%(95 \% \mathrm{Cl}: 1.38-1.81 \%, P<0.001), 0.94 \%$ (95\% Cl: $0.73-1.15 \%, P<0.001)$, and $0.39 \%(95 \% \mathrm{Cl}: 0.18-0.6 \%, P=0.059)$ increase in the risk of eczema outpatient visits at lag $0-3$ days, respectively, in the male group. On the other hand, the percentage change of eczema outpatient visits in the female group were $1.97 \%(95 \% \mathrm{Cl}: 1.75-2.19 \%, P<0.001)$, $1.71 \%$ (95\%Cl: $1.48-1.93 \%, P<0.001), 1.01 \%$ (95\%Cl: $0.79-1.23 \%, P<0.001)$, and $0.65 \%(95 \% \mathrm{Cl}: 0.43-0.86 \%, P=0.002)$ at lag $0-3$ days, respectively. Results obtained after age stratification analyses indicated that the strongest positive association between $\mathrm{PM}_{10}$ exposure and eczema were also observed at lag 0 day with the percent changes being $3.74 \%(95 \% \mathrm{Cl}, 3.34-4.14 \%, P<0.001), 1.66 \%(95 \% \mathrm{Cl}, 1.47-1.86 \%, P<0.001)$, and $2.55 \%(95 \% \mathrm{Cl}$ : $2.24-2.87 \%, P<0.001)$ among the three age groups. Similarly, gradual weakening trends could also be observed at lag $1-3$ days (Table 4$)$. In addition, $\mathrm{PM}_{2.5}$ and $\mathrm{PM}_{10}$ had similar effects on the number of eczema outpatients in both the two-pollutant model and the single pollutant model (Table 5). 
Table 4

Stratification analysis of the percent change of eczema risk associated with a $10 \mathrm{mg} / \mathrm{m}^{3}$ increase of $\mathrm{PM}_{2.5}$ and $\mathrm{PM}_{10}$

\begin{tabular}{|c|c|c|c|c|c|c|c|c|c|c|c|}
\hline & & Male & & Female & & $<12$ & & $12-64$ & & $\geq 65$ & \\
\hline $\begin{array}{l}\text { Pollutant } \\
\text { (per } \\
10 \mathrm{mg} / \mathrm{m}^{3} \text { ) }\end{array}$ & $\begin{array}{l}\text { Lag } \\
\text { Day }\end{array}$ & PC (\%) & p_value & PC (\%) & p_value & PC (\%) & p_value & PC (\%) & p_value & PC (\%) & p_value \\
\hline \multirow[t]{4}{*}{$\mathrm{PM}_{2.5}$} & $\begin{array}{l}\text { Lag } \\
0\end{array}$ & $\begin{array}{l}2.32(2.03- \\
2.61)\end{array}$ & $<.001$ & $\begin{array}{l}2.31(2.01- \\
2.61)\end{array}$ & $<.001$ & $\begin{array}{l}4.72(4.18- \\
5.28)\end{array}$ & $<.001$ & $\begin{array}{l}1.92(1.65- \\
2.19)\end{array}$ & $<.001$ & $\begin{array}{l}3.34(2.9- \\
3.78)\end{array}$ & $<.001$ \\
\hline & $\begin{array}{l}\mathrm{Lag} \\
1\end{array}$ & $\begin{array}{l}1.77(1.47- \\
2.07)\end{array}$ & $<.001$ & $\begin{array}{l}1.82(1.51- \\
2.13)\end{array}$ & $<.001$ & $\begin{array}{l}3.11(2.54- \\
3.68)\end{array}$ & $<.001$ & $\begin{array}{l}1.59(1.31- \\
1.87)\end{array}$ & $<.001$ & $\begin{array}{l}2.27(1.82- \\
2.73)\end{array}$ & $<.001$ \\
\hline & $\begin{array}{l}\operatorname{Lag} \\
2\end{array}$ & $\begin{array}{l}0.9(0.61- \\
1.19)\end{array}$ & 0.002 & $\begin{array}{l}0.99(0.68- \\
1.29)\end{array}$ & 0.001 & $\begin{array}{l}0.91(0.36- \\
1.46)\end{array}$ & 0.096 & $\begin{array}{l}0.84(0.57- \\
1.12)\end{array}$ & 0.002 & $\begin{array}{l}1.59(1.14- \\
2.03)\end{array}$ & $<.001$ \\
\hline & $\begin{array}{l}\text { Lag } \\
3\end{array}$ & $\begin{array}{l}0.16(-0.13- \\
0.44)\end{array}$ & 0.579 & $\begin{array}{l}0.41(0.12- \\
0.71)\end{array}$ & 0.160 & $\begin{array}{l}-0.74(-1.26- \\
-0.22)\end{array}$ & 0.159 & $\begin{array}{l}0.3(0.03- \\
0.56)\end{array}$ & 0.26 & $\begin{array}{l}1.15(0.72- \\
1.59)\end{array}$ & 0.008 \\
\hline \multirow[t]{4}{*}{$\mathrm{PM}_{10}$} & $\begin{array}{l}\text { Lag } \\
0\end{array}$ & $\begin{array}{l}1.97(1.76- \\
2.18)\end{array}$ & $<.001$ & $\begin{array}{l}1.97(1.75- \\
2.19)\end{array}$ & $<.001$ & $\begin{array}{l}3.74(3.34- \\
4.14)\end{array}$ & $<.001$ & $\begin{array}{l}1.66(1.47- \\
1.86)\end{array}$ & $<.001$ & $\begin{array}{l}2.55(2.24- \\
2.87)\end{array}$ & $<.001$ \\
\hline & $\begin{array}{l}\text { Lag } \\
1\end{array}$ & $\begin{array}{l}1.6(1.38- \\
1.81)\end{array}$ & $<.001$ & $\begin{array}{l}1.71(1.48- \\
1.93)\end{array}$ & $<.001$ & $\begin{array}{l}2.81(2.4- \\
3.23)\end{array}$ & $<.001$ & $\begin{array}{l}1.46(1.26- \\
1.66)\end{array}$ & $<.001$ & $\begin{array}{l}1.9(1.57- \\
2.23)\end{array}$ & $<.001$ \\
\hline & $\begin{array}{l}\operatorname{Lag} \\
2\end{array}$ & $\begin{array}{l}0.94(0.73- \\
1.15)\end{array}$ & $<.001$ & $\begin{array}{l}1.01(0.79- \\
1.23)\end{array}$ & $<.001$ & $\begin{array}{l}1.16(0.77- \\
1.56)\end{array}$ & 0.003 & $\begin{array}{l}0.88(0.69- \\
1.08)\end{array}$ & $<.001$ & $\begin{array}{l}1.27(0.95- \\
1.59)\end{array}$ & $<.001$ \\
\hline & $\begin{array}{l}\text { Lag } \\
3\end{array}$ & $\begin{array}{l}0.39(0.18- \\
0.6)\end{array}$ & 0.059 & $\begin{array}{l}0.65(0.43- \\
0.86)\end{array}$ & 0.002 & $\begin{array}{l}-0.27(-0.64- \\
0.12)\end{array}$ & 0.485 & $\begin{array}{l}0.53(0.33- \\
0.72)\end{array}$ & 0.006 & $\begin{array}{l}0.99(0.68- \\
1.3)\end{array}$ & 0.002 \\
\hline
\end{tabular}

Table 5

Stratification analysis of the percent change of eczema risk associated with a $10 \mathrm{mg} / \mathrm{m}^{3}$ increase of $\mathrm{PM}_{2.5}$ and $\mathrm{PM}_{10}$ under the twopollutant model

\begin{tabular}{|c|c|c|c|c|c|c|}
\hline $\begin{array}{l}\text { Pollutant } \\
\text { (per } 10 \mathrm{mg} / \mathrm{m}^{3} \text { ) }\end{array}$ & Model type & Male & Female & $<12$ & $12-64$ & $\geq 65$ \\
\hline \multirow[t]{4}{*}{$\mathrm{PM}_{2.5}{ }^{*}$} & $\mathrm{PM}_{2.5}+\mathrm{PM}_{10}$ & $1.24(1.06-1.41)$ & $1.34(1.17-1.52)$ & $1.86(1.54-2.18)$ & $1.13(0.97-1.3)$ & $1.81(1.55-2.07)$ \\
\hline & $\mathrm{PM}_{2.5}+\mathrm{NO}_{2}$ & $1.96(1.73-2.19)$ & $2.04(1.81-2.28)$ & $2.65(2.22-3.08)$ & $1.79(1.58-2.01)$ & $2.67(2.32-3.02)$ \\
\hline & $\mathrm{PM}_{2.5}+\mathrm{SO}_{2}$ & $2.46(2.12-2.79)$ & $2.6(2.25-2.94)$ & $3.71(3.09-4.34)$ & $2.22(1.91-2.54)$ & $3.65(3.15-4.16)$ \\
\hline & $\mathrm{PM}_{2.5}+\mathrm{O}_{3}$ & $1.41(1.22-1.59)$ & $1.52(1.33-1.71)$ & $2.55(2.2-2.89)$ & $1.26(1.09-1.43)$ & $2.02(1.74-2.3)$ \\
\hline \multirow[t]{3}{*}{ PM10* } & $\mathrm{PM}_{2.5}+\mathrm{NO}_{2}$ & $1.69(1.51-1.88)$ & $1.8(1.61-1.99)$ & $2.35(2-2.7)$ & $1.57(1.4-1.74)$ & $2.19(1.91-2.47)$ \\
\hline & $\mathrm{PM}_{2.5}+\mathrm{SO}_{2}$ & $2.25(2-2.51)$ & $2.42(2.15-2.68)$ & $3.38(2.9-3.87)$ & $2.07(1.84-2.31)$ & $3.03(2.64-3.41)$ \\
\hline & $\mathrm{PM}_{2.5}+\mathrm{O}_{3}$ & $1.34(1.19-1.5)$ & $1.46(1.3-1.62)$ & $2.33(2.03-2.62)$ & $1.22(1.07-1.37)$ & $1.82(1.58-2.06)$ \\
\hline
\end{tabular}

\section{Sensitivity Analyses}

The obtained results after sensitivity analyses done in this study showed that the effect estimates of $\mathrm{PM}_{2.5}$ and $\mathrm{PM}_{10}$ were not materially influenced by changing the $\mathrm{df}$ for the smooth function of time trend indicating the credibility of our results (Supplementary Table 3).

\section{Discussion}

This study investigated the correlations between meteorological and environmental factors with the number of eczema outpatient visits in Guangzhou. In total,293,343 cases of eczema were analyzed using $\mathrm{PM}_{2.5}$ and $\mathrm{PM}_{10}$. The obtained results suggested that the increasing concentrations of air pollutants were significantly associated with the rising number of eczema cases. A $10 \mu \mathrm{g} / \mathrm{m}^{3}$ increase of $\mathrm{PM}_{2.5}$ on the same day/ lag 1 day/ lag 2 days was associated with increments of $2.33 \%(2.06-2.6 \%), 1.81 \%(1.53-2.09 \%)$, and $0.95 \%(0.68-1.23 \%)$ in the eczema outpatients risk, respectively. Similarly, a $10 \mu \mathrm{g} / \mathrm{m}^{3}$ increase of $\mathrm{PM}_{10}$ was associated with eczema outpatients risk increments of $1.97 \%(1.77-2.17 \%), 1.65 \%(1.45-1.86 \%)$, and $0.98 \%(0.78-1.18 \%)$ at the same day/ lag 1 day/ lag 2 days, respectively. 
The number of outpatient visits has been widely used in environmental epidemiology studies to estimate the influence of air pollutants on eczema. The confounders including seasonal changes and long-term trends can be modified using the distributed lag nonlinear model ${ }^{25-27}$. Previous studies conducted in Shanghai and Chengdu, two representative cities with high urbanization in China, have reported that multiple air pollutants in both cities had the potential of increasing the incidence and prevalence of eczema ${ }^{28,29}$. The conclusions from both studies are consistent with results obtained in this study. In addition, Dong et al., suggested that raising public awareness is crucial for constantly improving the air quality. This is because PM is not only associated with cardiovascular and respiratory issues but it also has a positive connection with the occurrence of skin diseases in China ${ }^{30}$. Although a decreasing tendency in the levels of PM concentrations was observed from 2013 in the main regions in China including the Beijing-TianjinHubei region, Yangtze River Delta, and Pearl River Delta, the recorded concentration levels still exceeded the limits recommended by the World Health Organization and Chinese authorities ${ }^{31}$. With the acceleration of economic and industrial development, air pollution will most likely be an inevitable issue, particularly in the developing countries.

Generally, identification of vulnerable groups is of great significance for public health prevention. The existing evidences have limitations in revealing whether the effects of air pollution on eczema differ in population subgroups. Therefore, we stratified the eczema cases into three groups including $<12$, $\geq 12$ and $<65$, and $\geq 65$ years old. The obtained results indicated that children $(<12)$ and the elderly $(\geq 65)$ were more vulnerable to adverse effects of short-term exposure to PM. The skin, which is the largest organ in the human body, contains four different barrier components including physical, chemical, microbial, and immunological barriers ${ }^{32}$. The physical barrier, which mainly consists of the stratum corneum, can exert the protection function against penetration of pathogens, allergens, and several other exogenous air pollutants such as $\mathrm{PM}, \mathrm{NO}_{2}$, and $\mathrm{SO}_{2}{ }^{33,34}$. A healthy skin barrier plays an essential role of preventing damage caused by stimuli including air pollutants. The vulnerable groups can easily suffer from eczema after short-term exposure to PM due to the immature and aging skin barrier in children and the elderly, respectively. Undeveloped sebaceous glands, skin infections, and local immune dysregulation are the main reasons for epidermal barrier abnormalities in children ${ }^{35-37}$.On the other hand, epidermal dysfunction, compromised permeability homeostasis, reduced stratum corneum hydration, and elevated skin surface $\mathrm{pH}$ are the aggressive factors for the elderly 37 ,

${ }^{38}$. Therefore, this study suggests that children and the elderly should avoid staying outdoors frequently to prevent PM exposure, which will potentially decrease the risk of eczema.

However, the mechanisms of how PM induces and aggravates eczema in humans have not yet been elucidated. It is likely that PM induces the disruption of the epidermis by modulating the structural proteins including small proline-rich (SPRR) family, occludens-1 (ZO-1), keratins, filaggrin, and claudin- ${ }^{39-45}$, thereby resulting in both increased epithelial and endothelial barrier permeability ${ }^{46}$. Moreover, a previous study reported that the penetration of PM was observed in both intact and barrier-disrupted skin in vivo, resulting in inflammatory responses ${ }^{47}$. Current scientific opinions on the down-stream mechanisms through which air pollutants affect skin health mainly include: 1) elevation of oxidative stress via exogenous and endogenous reactive oxygen species (ROS) generation, which is a series of a highly reactive chemical substances. Numerous evidences have suggested that PM can induce direct and indirect ROS formation, resulting in lipid, protein, and DNA damage ${ }^{10,48,49}$; 2 ) activation of the aryl hydrocarbon receptor $(A h R)$, which further limits cell proliferation and implicates in skin senescence ${ }^{50} ; 3$ ) activation of the inflammatory cascade in skin and impairing of the immunological barrier $39,43,51 ; 4)$ activation of toll-like receptors, NF-KB, and MAPK signaling pathways ${ }^{52-56}$; and 5 ) induction of apoptosis and autophagy 57,58 . Currently, the clinical management strategies for eczema mainly include the administration of moisturizers, topical corticosteroids, and calcineurin inhibitors, representing an anti-allergen and anti-inflammation strategy. Since the skin is the most important defense barrier against environmental contaminants, future research should elucidate the clear mechanism of how air pollutants aggravate eczema in humans with the overarching goal of providing recommendations for improving skin protection against air pollution.

To the best of our knowledge, this is the first study which has uncovered the associations and lagged effects between exposure to environmental factors and number of eczema outpatients in Guangzhou, southern China. However, the study has several potential limitations. Firstly, the study used data on the number of eczema outpatient visits to estimate the effect of exposure to PM rather than using authentic physiological records or measurements. In addition, the clinical cases were only selected from one hospital. Although the hospital selection bias might be inevitable, the Dermatology Hospital of Southern Medical University is one of the largest and representative dermatological departments among the local hospitals. Therefore, it can be used to reflect the trend of eczema outpatient visits from the whole region. Secondly, the data on the exposure of individuals to the environmental factors was unavailable. Furthermore, the outdoor average concentrations of $\mathrm{PM}_{2.5}, \mathrm{PM}_{10}, \mathrm{NO}_{2}, \mathrm{SO}_{2}$, and $\mathrm{O}_{3}$ were recorded as the average obtained from the different fixed monitoring stations, which may raise errors in documented measurements. Thirdly, the study does not include detailed information on the severity of eczema and the differentiation of initial onset or relapsing cases, which may lead to bias while interpreting the results. However, our study still offers considerable evidence on the relationship between environmental factors and the prevalence of eczema, thereby proposing highlights for promoting the policies and actions which will lead to the reduction of air pollution for a better skin condition.

\section{Conclusion}

This study has contributed to the limited scientific evidence which suggests that $\mathrm{PM}_{2.5}$ and $\mathrm{PM}_{10}$ may induce and aggravate eczema especially among children and the elderly, and has provided considerable public health concerns on skin diseases. The study provided a further understanding of the relationship between air pollutants and eczema, which will aid in disease prevention and lower the health burden.

\section{List Of Abbreviations}


PM: particulate matter; GAM: generalized additive model; ICD-10: International Classification of Diseases, the 10th version; DOW: day of week; Q-AIC: Akaike information criterion for quasi-Poisson; SPRR: small proline-rich; ROS: reactive oxygen species; AhR: aryl hydrocarbon receptor

\section{Declarations}

\section{Acknowledgements}

Not applicable.

\section{Authors' contributions}

SS and JC designed the study. JZ, JX and DJ analyzed the data. YY drafted the manuscript. BS, YC contributed to the data collection. All authors critically reviewed and approved the manuscript.

\section{Funding}

Not applicable.

\section{Availability of data and materials}

The air pollution data that support the findings of this study are available on request from the corresponding author, Qing Chen. The eczema data are not publicly available due to the privacy restriction.

\section{Ethics approval and consent to participate}

The protocol of study and accessing the hospital admission data was approved by the ethics committee of Dermatology Hospital, Southern Medical University, and was performed in accordance with the ethical standards noted in the 1964 Declaration of Helsinki and its later amendments.

\section{Consent for publication}

Not applicable.

\section{Competing interests.}

The authors declare they have no competing interests.

${ }^{1}$ Zhujiang Hospital, Southern Medical University, 253\#, Gongye Avenue, Guangzhou, Guangdong Province, People's Republic of China, 510000. ${ }^{2}$ State Key Laboratory of Cardiovascular Disease, Fuwai Hospital, National Center for Cardiovascular Diseases, Chinese Academy of Medical Sciences and Peking Union Medical College. Beijing, People's Republic of China, $100037 .{ }^{3}$ Department of Public Health, Southern Medical University, 1838\#Guangzhou North Avenue, Guangzhou, People's Republic of China, 510515. ${ }^{4}$ Department of Cardiology, Guangdong Cardiovascular institute, Guangdong Provincial People's Hospital, Guangdong Academy of Medical Sciences, School of Medicine, South China University of Technology, Guangzhou, People's Republic of China, 510641. ${ }^{5}$ Dermatology Hospital, Southern Medical University. 2\#囚 Lujing Road, Yuexiu District, Guangzhou, People's Republic of China, 510000

\section{References}

1. Deckers I, McLean S, Linssen S, Mommers M, van Schayck C, Sheikh A. Investigating international time trends in the incidence and prevalence of atopic eczema 1990-2010: A systematic review of epidemiological studies. PloS one. 2012;7:e39803

2. Nutten S. Atopic dermatitis: Global epidemiology and risk factors. Annals of nutrition \& metabolism. 2015:8-16

3. Karimkhani C, Dellavalle R, Coffeng L, Flohr C, Hay R, Langan S, Nsoesie E, Ferrari A, Erskine H, Silverberg J, Vos T, Naghavi M. Global skin disease morbidity and mortality: An update from the global burden of disease study 2013. JAMA dermatology. 2017;153:406-412

4. Behrendt $\mathrm{H}$, Alessandrini F, Buters J, Krämer U, Koren H, Ring J. Environmental pollution and allergy: Historical aspects. Chemical immunology and allergy. 2014;100:268-277

5. Chong M, Fonacier L. Treatment of eczema: Corticosteroids and beyond. Clinical reviews in allergy \& immunology. 2016;51:249-262

6. Blome C, Radtke M, Eissing L, Augustin M. Quality of life in patients with atopic dermatitis: Disease burden, measurement, and treatment benefit. American journal of clinical dermatology. 2016;17:163-169 
7. Kan H, Chen R, Tong S. Ambient air pollution, climate change, and population health in china. Environment international. 2012;42:10-19

8. Zhang Q, He K, Huo H. Policy: Cleaning china's air. Nature. 2012;484:161-162

9. Kampa M, Castanas E. Human health effects of air pollution. Environmental pollution (Barking, Essex : 1987). 2008;151:362-367

10. Dijkhoff I, Drasler B, Karakocak B, Petri-Fink A, Valacchi G, Eeman M, Rothen-Rutishauser B. Impact of airborne particulate matter on skin: A systematic review from epidemiology to in vitro studies. Particle and fibre toxicology. 2020;17:35

11. Carlsten C, Melén E. Air pollution, genetics, and allergy: An update. Current opinion in allergy and clinical immunology. 2012;12:455-460

12. Chang W, Lee C, Hirota T, Wang L, Doi S, Miyatake A, Enomoto T, Tomita K, Sakashita M, Yamada T, Fujieda S, Ebe K, Saeki H, Takeuchi S, Furue M, Chen W, Chiu Y, Chang W, Hong C, Hsi E, Juo S, Yu H, Nakamura Y, Tamari M. Orai1 genetic polymorphisms associated with the susceptibility of atopic dermatitis in japanese and taiwanese populations. PloS one. 2012;7:e29387

13. Apfelbacher C, Diepgen T, Schmitt J. Determinants of eczema: Population-based cross-sectional study in germany. Allergy. 2011;66:206-213

14. Kantor R, Silverberg J. Environmental risk factors and their role in the management of atopic dermatitis. Expert review of clinical immunology. 2017;13:15-26

15. Kabashima K, Otsuka A, Nomura T. Linking air pollution to atopic dermatitis. Nature immunology. 2016;18:5-6

16. Ngoc L, Park D, Lee Y, Lee Y. Systematic review and meta-analysis of human skin diseases due to particulate matter. International journal of environmental research and public health. 2017;14

17. Aguilera I, Pedersen M, Garcia-Esteban R, Ballester F, Basterrechea M, Esplugues A, Fernández-Somoano A, Lertxundi A, Tardón A, Sunyer J. Earlylife exposure to outdoor air pollution and respiratory health, ear infections, and eczema in infants from the inma study. Environmental health perspectives. 2013;121:387-392

18. Guo P, Wang Y, Feng W, Wu J, Fu C, Deng H, Huang J, Wang L, Zheng M, Liu H. Ambient air pollution and risk for ischemic stroke: A short-term exposure assessment in south china. International journal of environmental research and public health. 2017;14

19. http://sthjj.gz.gov.cn/zwgk/hjgb/content/post_5611849.html.

20. Ravindra K, Rattan P, Mor S, Aggarwal A. Generalized additive models: Building evidence of air pollution, climate change and human health. Environment international. 2019;132:104987

21. Schwartz J. Harvesting and long term exposure effects in the relation between air pollution and mortality. American journal of epidemiology. 2000;151:440-448

22. Shen S, Li X, Yuan C, Huang Q, Liu D, Ma S, Hui J, Liu R, Wu T, Chen Q. Association of short-term exposure to sulfur dioxide and hospitalization for ischemic and hemorrhagic stroke in guangzhou, china. BMC public health. 2020;20:263

23. Zhou M, Wang L, Liu T, Zhang Y, Lin H, Luo Y, Xiao J, Zeng W, Zhang Y, Wang X, Gu X, Rutherford S, Chu C, Ma W. Health impact of the 2008 cold spell on mortality in subtropical china: The climate and health impact national assessment study (chinas). Environmental health : a global access science source. 2014;13:60

24. Yin P, Chen R, Wang L, Liu C, Niu Y, Wang W, Jiang Y, Liu Y, Liu J, Qi J, You J, Zhou M, Kan H. The added effects of heatwaves on cause-specific mortality: A nationwide analysis in 272 chinese cities. Environment international. 2018;121:898-905

25. Bhaskaran K, Gasparrini A, Hajat S, Smeeth L, Armstrong B. Time series regression studies in environmental epidemiology. International journal of epidemiology. 2013;42:1187-1195

26. Dhadwal G, Albrecht L, Gniadecki R, Poulin Y, Yeung J, Hong C, Gooderham M. Approach to the assessment and management of adult patients with atopic dermatitis: A consensus document. Section iv: Treatment options for the management of atopic dermatitis. Journal of cutaneous medicine and surgery. 2018;22:21S-29S

27. Chow S, Seow C, Dizon M, Godse K, Foong H, Chan V, Khang T, Xiang L, Hidayat S, Listiawan M, Triwahyudi D, Gondokaryono S, Sutedja E, Diana I, Suwarsa O, Dharmadji H, Siswati A, Danarti R, Soebaryo R, Budianti W. A clinician's reference guide for the management of atopic dermatitis in asians. Asia Pacific allergy. 2018;8:e41

28. Li Q, Yang Y, Chen R, Kan H, Song W, Tan J, Xu F, Xu J. Ambient air pollution, meteorological factors and outpatient visits for eczema in shanghai, china: A time-series analysis. International journal of environmental research and public health. 2016;13

29. Li A, Fan L, Xie L, Ren Y, Li L. Associations between air pollution, climate factors and outpatient visits for eczema in west china hospital, chengdu, south-western china: A time series analysis. Journal of the European Academy of Dermatology and Venereology : JEADV. 2018;32:486-494

30. Dong Y, Liao L, Li L, Yi F, Meng H, He Y, Guo M. Skin inflammation induced by ambient particulate matter in china. The Science of the total environment. 2019;682:364-373

31. Zhang Z, Wang J, Hart JE, Laden F, Zhao C, Li T, Zheng P, Li D, Ye Z, Chen K. National scale spatiotemporal land-use regression model for pm2.5, pm10 and no2 concentration in china. Atmospheric Environment. 2018;192:48-54

32. Grice E, Segre J. The skin microbiome. Nature reviews. Microbiology. 2011;9:244-253

33. Scheuplein R, Blank I. Permeability of the skin. Physiological reviews. 1971;51:702-747

34. Madison K. Barrier function of the skin: "La raison d'être" of the epidermis. The Journal of investigative dermatology. 2003;121:231-241

35. Gupta J, Grube E, Ericksen M, Stevenson M, Lucky A, Sheth A, Assa'ad A, Khurana Hershey G. Intrinsically defective skin barrier function in children with atopic dermatitis correlates with disease severity. The Journal of allergy and clinical immunology. 2008;121:725-730.e722

Page 9/10 
36. Cork M, Danby S, Vasilopoulos Y, Hadgraft J, Lane M, Moustafa M, Guy R, Macgowan A, Tazi-Ahnini R, Ward S. Epidermal barrier dysfunction in atopic dermatitis. The Journal of investigative dermatology. 2009;129:1892-1908

37. Ramos-e-Silva M, Boza J, Cestari T. Effects of age (neonates and elderly) on skin barrier function. Clinics in dermatology. 2012;30:274-276

38. Wang Z, Man M, Li T, Elias P, Mauro T. Aging-associated alterations in epidermal function and their clinical significance. Aging. 2020;12:5551-5565

39. Kim H, Bae I, Son E, Park J, Cha N, Na H, Jung C, Go Y, Kim D, Lee T, Shin D. Transcriptome analysis of airborne pm-induced detrimental effects on human keratinocytes. Toxicology letters. 2017;273:26-35

40. Bae J, Choi H, Shin D, Na H, Park N, Kim J, Jo D, Cho M, Lyu J, Chang J, Lee E, Lee T, Kim H, Cho D. Fine particulate matter (pm2.5) inhibits ciliogenesis by increasing sprr3 expression via c-jun activation in rpe cells and skin keratinocytes. Scientific reports. 2019;9:3994

41. Lehmann A, Blank F, Baum O, Gehr P, Rothen-Rutishauser B. Diesel exhaust particles modulate the tight junction protein occludin in lung cells in vitro. Particle and fibre toxicology. 2009;6:26

42. Pan T, Wang P, Aljuffali I, Huang C, Lee C, Fang J. The impact of urban particulate pollution on skin barrier function and the subsequent drug absorption. Journal of dermatological science. 2015;78:51-60

43. Jin S, Li Z, Choi E, Lee S, Kim Y, Seo E, Chung J, Cho S. Urban particulate matter in air pollution penetrates into the barrier-disrupted skin and produces ros-dependent cutaneous inflammatory response in vivo. Journal of dermatological science. 2018

44. Lee C, Lin Z, Hu S, Chiang Y, Hsu L, Lin Y, Lee I, Tsai M, Fang J. Urban particulate matter down-regulates filaggrin via cox2 expression/pge2 production leading to skin barrier dysfunction. Scientific reports. 2016;6:27995

45. Zhao R, Guo Z, Zhang R, Deng C, Xu J, Dong W, Hong Z, Yu H, Situ H, Liu C, Zhuang G. Nasal epithelial barrier disruption by particulate matter $\leq 2.5$ $\mu \mathrm{m}$ via tight junction protein degradation. Journal of applied toxicology : JAT. 2018;38:678-687

46. Wang T, Wang L, Moreno-Vinasco L, Lang G, Siegler J, Mathew B, Usatyuk P, Samet J, Geyh A, Breysse P, Natarajan V, Garcia J. Particulate matter air pollution disrupts endothelial cell barrier via calpain-mediated tight junction protein degradation. Particle and fibre toxicology. 2012;9:35

47. Ali M, Sayeski P, Safavi A, Lyles M, Bernstein K. Janus kinase 2 (jak2) must be catalytically active to associate with the at1 receptor in response to angiotensin ii. Biochem Biophys Res Commun. 1998;249:672-677

48. Øvrevik J, Refsnes M, Låg M, Holme J, Schwarze P. Activation of proinflammatory responses in cells of the airway mucosa by particulate matter: Oxidant- and non-oxidant-mediated triggering mechanisms. Biomolecules. 2015;5:1399-1440

49. Fang T, Lakey P, Weber R, Shiraiwa M. Oxidative potential of particulate matter and generation of reactive oxygen species in epithelial lining fluid. Environmental science \& technology. 2019;53:12784-12792

50. Ryu Y, Kang K, Piao M, Ahn M, Yi J, Bossis G, Hyun Y, Park C, Hyun J. Particulate matter-induced senescence of skin keratinocytes involves oxidative stress-dependent epigenetic modifications. Exp Mol Med. 2019;51:1-14

51. Ushio H, Nohara K, Fujimaki H. Effect of environmental pollutants on the production of pro-inflammatory cytokines by normal human dermal keratinocytes. Toxicology letters. 1999;105:17-24

52. Kaisho T, Akira S. Toll-like receptor function and signaling. The Journal of allergy and clinical immunology. 2006;117:979-987; quiz 988

53. Lebre M, van der Aar A, van Baarsen L, van Capel T, Schuitemaker J, Kapsenberg M, de Jong E. Human keratinocytes express functional toll-like receptor 3, 4, 5, and 9. The Journal of investigative dermatology. 2007;127:331-341

54. Liu T, Zhang L, Joo D, Sun S. Nf-kb signaling in inflammation. Signal transduction and targeted therapy. 2017;2

55. Smith W, Garavito R, DeWitt D. Prostaglandin endoperoxide h synthases (cyclooxygenases)-1 and -2. The Journal of biological chemistry. $1996 ; 271: 33157-33160$

56. Kawai T, Akira S. TIr signaling. Cell death and differentiation. 2006;13:816-825

57. Zhen A, Piao M, Hyun Y, Kang K, Madushan Fernando P, Cho S, Ahn M, Hyun J. Diphlorethohydroxycarmalol attenuates fine particulate matterinduced subcellular skin dysfunction. Marine drugs. 2019;17

58. Piao M, Kang K, Zhen A, Fernando P, Ahn M, Koh Y, Kang H, Yi J, Choi Y, Hyun J. Particulate matter 2.5 mediates cutaneous cellular injury by inducing mitochondria-associated endoplasmic reticulum stress: Protective effects of ginsenoside rb1. Antioxidants (Basel, Switzerland). 2019;8

\section{Supplementary Files}

This is a list of supplementary files associated with this preprint. Click to download.

- SupplementaryTablesPM1014.docx

- SupplementaryTablesPM1014.docx 